Jurnal Kesehatan Masyarakat (J-KESMAS)

Vol. 07, No. 1, Mei 2021, Halaman 52-58

e-ISSN: 2541-4542. DOI: http://dx.doi.org/10.35329/jkesmas.v7i1

\title{
Hubungan Dukungan Suami Dengan Kejadian Post Partum Blues Di Wilayah Perkotaan
}

\author{
Samria $^{1}$, Indah Haerunnisa ${ }^{2}$
}

STIKES Bina Generasi Polewali Mandar,Jl Mr Muh Yamin No.195 Manding,Polewali Mandar,Sulawesi Barat,91315, Indonesia

\begin{tabular}{|c|c|}
\hline Article Info & ABSTRACT \\
\hline $\begin{array}{l}\text { Article history: } \\
\text { Received Apr 30, } 2021 \\
\text { Revised Mei 03, } 2021 \\
\text { Accepted Mei 25, } 2021\end{array}$ & $\begin{array}{l}\text { Post partum is the period after giving birth to the } \\
\text { recovery of the uterus and female organs which is } \\
\text { generally accompanied by the discharge of postpartum } \\
\text { blood.The length of the post partum period is around 6-8 }\end{array}$ \\
\hline Keywords: & period will also result in changes in psychological \\
\hline $\begin{array}{l}\text { Support Husband, Post Partum } \\
\text { Blues, city. }\end{array}$ & $\begin{array}{l}\text { conditions. Research Objectives To determine the } \\
\text { relationship between husband's support and the incidence } \\
\text { of post partum blues in urban areas. The research method } \\
\text { used was analytic survey research design and cross } \\
\text { sectional approach. The number of samples is } 40 \text { people. } \\
\text { Sampling using a support questionnaire. The results of } \\
\text { the analysis of the relationship between the two variables } \\
\text { above by using the chi-square statistical test obtained the } \\
\text { significance of the relationship between the two variables } \\
\text { is } p=0.000, p=0.000<\alpha 0.05 \text {, this means that Ha is } \\
\text { accepted and Ho is rejected, so there is a relationship. } \\
\text { husband's support with the incidence of post partum blues } \\
\text { in urban areas. Suggestion Can provide health education } \\
\text { and education to postpartum mothers by presenting a } \\
\text { husband as a companion to the mother so that the risk of } \\
\text { post partum blues can be better prevented. }\end{array}$ \\
\hline
\end{tabular}

\section{Corresponding Author:}

Samria ${ }^{1}$ Indah Haerunnisa ${ }^{2}$,

STIKES Bina Generasi Polewali Mandar, Fakultas Ilmu Keperawatan. Jl Mr Muh Yamin No 195

Manding,Polewali Mandar,Sulawesi Barat,91315, Indonesia

samria923@gmail.com2indahnisa910@gmail.com

Journal homepage: https://journal.lppm-unasman.ac.id/index.php/jikm/index 


\section{PENDAHULUAN}

Postpartum blues adalah keadaan dimana seorang ibu mengalami perasaan tidak nyaman setelah persalinan yang berkaitan dengan hubungan ibu dan bayinya atau dengan dirinya sendiri. Saat plasenta dikeluarkan pada serangkaian proses persalinan terjadi perubahan hormon yang melibatkan progesteron, dan estrogen dalam tubuh seorang wanita yang dapat mempengaruhi kondisifisik,mental dan emosional ibu.

Postpartum blues dapat berkembang menjadi gejala depresi mayor. Lebih dari $20 \%$ wanita yang mengalami postpartum blues akan berkembang menjadi gejala depresi mayor dalam satu tahun setelah melahirkan (Reck et al., 2009). Apabila postpartum blues tidak ditangani dengan serius, maka akan berkembang menjadi depresi postpartum dan kondisi yang paling berat bisa sampai postpartum psychosis. Postpartum blues sering menyebabkan terputusnya interaksi ibu dan anak, dan mengganggu perhatian dan bimbingan yang dibutuhkan bayinya untuk berkembang secara baik (Ishikawa et al., 2011). Panduan obstetric dan gynecology, menyakini $10-15 \%$ ibu yang melahirkan mengalami gangguan ini dan hampir $90 \%$ mereka tidak mengetahui postpartum blues.

Angka kejadian post partum blues di Asia cukup tinggi dan bervariasi antara 26-85 $\%$, sedangkan di Indonesia angka kejadian post partum blues antara 50-70 \% wanita pasca persalinan diperkirakan angka kejadiannya rendah dibandingkan hal ini disebabkan oleh budaya dan sifat orang Indonesia yang cenderung lebih sabar dan menerima apa yang dialaminya baik itu peristiwa yang menyenangkan maupun menyedihkan.

Depresi postpartum sering terjadi pada masa adaptasi psikologis ibu masa nifas, walaupun insidensinya sulit untuk diketahui secara pasti namun diyakini $10-15 \%$ ibu melahirkan mengalami gangguan ini Gejala Baby Blues ditandai dengan reaksi depresi atau sedih, menangis, mudah tersinggung, cemas, perasaan yang labil, cenderung menyalahkan diri sendiri, gangguan tidur dan gangguan nafsu makan Penyebab post partum blues tidak dapat ditentukan secara pasti namun diduga dipengaruhi antara lain dikarenakan faktor internal dan eksternal Faktor internal.

Bagi ibu post partum, apabila pada ibu ibu yang baru pertama melahirkan akan sangat membutuhkan dukungan orang-orang terdekatnya karena ia belum sepenuhnya berada pada kondisi stabil, baik fisik maupun psikologisnya. Ia sangat asing dengan perubahan peran barunya yang begitu fantastis terjadi dalam waktu yng begitu cepat yaitu peran sebagai seorang ibu. Dengan respon positif dari suami, akan mempercepat proses adaptasi peran ini sehingga akan memudahkan bagi bidan untuk memberikan asuhan yang sehat.

Dukungan suami merupakan faktor terbesar dalam memicu kejadian postpartum blues. Hal ini dikarenakan dukungan suami merupakan strategi koping penting pada saat mengalami stress dan berfungsi sebagai strategi preventif untuk mengurangi stress. Mereka yang mendapatkan dukungan suami baik secara emosional, support,penghargaan relatif tidak menunjukkan gejala postpartum blues, sedangkan mereka yang kurang memperoleh dukungan suami relative mengalami gejala postpartum blues.Dukungan dari tenaga kesehatan seperti dokter obstetri bidan atau perawat juga sangat di perlukan oleh ibu 
postpartummisal dengan cara memberikan informasi yang memadai/ adekuat tentang proses kehamilan dan persalinan termasuk penyulit-penyulit yang mungkin akan timbul pada masa tersebut beserta penangannya.

Dasar karakteristik calon peneliti juga pada penelitian ini berawal dari melihat pentingnya dukungan dan informasi menurunkan kejadian post partum blues. Pengamatan pengamatan yang telah dilakukan peneliti melalui fenomena post partum berawal melihat hasil survey awal penelitian, membandingan kejadian post partum blues didaerah perdesaan dan perkotaan yang terdapat perbedaan. Diperdesaan yang notabene masyaraat tidak bekerja di luar rumah bagi kaum hawa dan diperkotaan cenderung sibuk dengan pekerjaan dan kegiatan, selain itu juga diketahui bahwa didesa minimnya informasi dan hiburan tetapi memiliki dukungan dari keluarga yang cukup lebih baik dibandingkan dikota yang lebih berpihak pada aktifitas rutin yang dapat menghambat kerja hormone yang bisa menimbulkan stress bahan depresi pada ibu nifas.

Berdasarkan penelitian Diah Ayu Fatmawati (2015) di Puskesmas wilayah kerja Kota Yogyakarta sebanyak 46\%, Proporsi ibu postpartum yang mengalami postpartum blues disebabkan oleh beberapa faktor, Faktor-faktor risiko mempunyai pengaruh terhadap kejadian postpartum blues pada ibu postpartum di Puskesmas wilayah kerja Kota Yogyakarta, paling berpengaruh terhadap kejadian postpartum blues pada ibu postpartum di Puskesmas wilayah kerja Kota Yogyakarta adalah faktor risiko usia ibu, Faktor risiko usia ibu, faktor paritas dan faktor dukungan sosial suami mempunyai pengaruh yang signifikan terhadap kejadian postpartum blues pada ibu postpartum di Puskesmas wilayah kerja Kota Yogyakarta, dan Faktor risiko pendidikan, faktor status pekerjaan ibu, faktor jenis persalinan, faktor kehamilan tidak diinginkan/direncanakan dan faktor status ekonomi keluarga tidak mempunyai pengaruh yang signifikan terhadap kejadian postpartum blues pada ibu postpartum di Puskesmas wilayah kerja Kota Yogyakarta, Hasil wawancara mendalam menunjukkan gambaran gejala postpartum blues lebih banyak terjadi adalah timbulnya kecemasan, kekhawatiran dan kesedihan pada ibu postpartum.

\section{METODE PENELITIAN}

Penelitian ini merupakan penelitian kuantitatif, dengan menggunakan desain penelitian survey analitk dengan pendekatan cross sectional.. Tekhnik pengambilan data Pengumpulan data pada penelitian ini menggunakan lembar kuesioner. Untuk mengukur kejadian post partum blues, peneliti menggunakan kuesioner dukungan. Teknik yang digunakan pada penelitian ini menggunakan purposive sampling dengan jumlah sampel sebanyak 40 responden. 


\section{HASIL DAN PEMBAHASAN}

Tabel 1 Hubungan Dukungan Suami dengan Kejadian Post Partum Blues di Wilayah perkotaan

\begin{tabular}{|c|c|c|c|c|c|}
\hline \multirow{4}{*}{$\begin{array}{l}\text { Kejadian Post } \\
\text { Partum Blues }\end{array}$} & \multirow[b]{3}{*}{ Menderita } & \multicolumn{2}{|c|}{ Dukungan Suami } & \multirow[t]{2}{*}{ Total } & \multirow[t]{2}{*}{ p-Value } \\
\hline & & Mendukung & Tidak Mendukung & & \\
\hline & & 6 & 19 & 25 & \multirow[t]{4}{*}{0,003} \\
\hline & $\%$ & $15 \%$ & $47,5 \%$ & $62,5 \%$ & \\
\hline & Tidak Menderita & 11 & 4 & 15 & \\
\hline & $\%$ & $27,5 \%$ & $10,0 \%$ & $37,5 \%$ & \\
\hline \multicolumn{2}{|r|}{ Total } & 17 & 23 & 40 & \\
\hline \multicolumn{2}{|r|}{$\%$} & $42,5 \%$ & $57,5 \%$ & $100,0 \%$ & \\
\hline
\end{tabular}

Hasil analisa hubungan kedua variabel diatas dengan menggunakan uji statistik chisquare didapat signifikansi dari hubungan kedua variabel tersebut adalah $\mathrm{p}=0.000, \mathrm{p}=$ $0,003<\alpha 0,05$ maka ini berarti Ha diterima dan Ho ditolak, maka ada hubungan dukungan suami dengan kejadian post partum blues di wilayah perkotaan Dari hasil penelitian didapatan bahwa dari 40 responden, sebagian besar responden menderita post partum blues yaitu sebanyak 6 responden (15\%) dan 19 responden yang tidak menderita post partum blues (25\%), sedangkan dukungan suami sebanyak $11(27,5 \%)$ dan tidak mendukung sebanyak 4 responden $(10,0 \%)$.

Seorang suami merupakan salah satu anggota keluarga yang sangat dekat dengan ibu. Segala bentuk tindakan yang dilakukan suami yang berkaitan dengan masa nifas ibu akan berdapak pada keadaan psikologis ibu serta kelancaran ibu dalam menjalani masa nifasnya. Dukungan yang positif dari suami sangat diperlukan dalam membantu kondisi ibu selama masa nifas. Apabila suami tidak mendukung ibu postpartum maka dapat membuat ibu merasa sedih dan kewalahan dalam mengasuh bayinya pada minggu pertama postpartum. Dukungan suami merupakan bentuk interaksi yang didalamnya terdapat hubungan yang saling memberi dan menerima bantuan yang bersifat nyata. Sehingga dapatmemberikan rasa cinta dan perhatian.

Menurut asumsi peneliti dengan melihat hasil pengolahan data tersebut menunjukkan bahwa responden yang mengalami post partum blues rata-rata adalah ibu-ibu yang tidak mendapatkan perhatian lebih dari keluarganya terutama suami. Ibu yang melahirkan dianggap sudah siap untuk mengasuh bayinya dan memenuhi kewajibanya sebagai ibu. Berdasarkan hasil wawancara peneliti dengan responden pada saat penelitian, hal tersebut disebabkan karena suami responden memiliki pekerjaan baik itu PNS maupun Wirausaha selain itu kurangnya perhatian dari keluarga/ orang tua yang disebabkan karena responden tinggal berjauhan dengan orang tuanya dan juga mertuanya atau sebagian diantara mereka sudah tidak mempunyai orang tua.

Ibu postpartum dikatakan postpartum blues ketika ibu postpartum mengalami perubahan mood yang terjadi setiap waktu setelah ibu melahirkan, tetapi sering terjadi pada hari ke-3 dan ke-4 postpartum dan memuncak antara hari ke-5 dan ke-14 pospartum 
yang ditandai dengan tangisan singkat, perasaan kesepian atau ditolak, cemas,bingung, gelisah, letih, pelupa, dan tidak dapat tidur.

Penyebab dari postpartum blues belum diketehui secara pasti, tapi diduga disebabkan oleh berbagai faktor, antara lain perubahan biologis, stress dan penyebab sosial atau lingkungan. Perubahan kadar hormon estrogen, progesteron, konrtikotropin dan endorphin serta prolaktin diduga menjadi faktor pendukung terjadinya postpartum blues. Faktor sosial dan lingkungan yang dapat menjadi faktor pendukung terjadinya postpartum blues antara lain tekanan dalam hubungan pernikahan dan hubungan keluarga, riwayat syndrome pramenstruasi, rasa cemas dan takut terhadappersalinan dan penyesuaian yang buruk terhadap peran maternal.

Hasil penelitian yang dilakukan oleh Yuliawan, D, (2014) mengenai dukungan suami terhadap kesejahteraan ibu nifas didapatkan hasil bahwa nilai rata-rata 296,61 dengan nilai terendah 156 dan nilai tertinggi 402 dan standar deviasi 50,257. Persentase dukungan suami pada penelitian yang dilakukanoleh Fatimah, S (2014) yaitu responden yang mendapatkan dukungan suami kurang sebanyak 4 orang (16\%), sedangkan responden yang mendapatkan dukungan suami sedang sebanyak 15 orang $(60 \%)$, dan responden yang mendapatkan dukungan suami tinggi sebanyak 6 orang (24\%).

Dari hasil penelitian sebagian besar responden tidak mendapatkan dukungan tersebut secara maksimal. Sebagaimana diketahui bahwa dukungan penuh dari suami adalah hal yang terpenting bagi ibu postpartum. Dukungan suami tidak dapat diremehkan dan sangat penting dalam membangun suasana positif. Oleh karena itu, dukungan atau sikap positif dari suami akan memberikan kekuatan tersendiri bagi ibu selama menjalani masa nifasnya.

Sesuai dengan pendapat Nirwana (2011) yaitu faktor yang mempengaruhi post partum blues adalah paktor psiologis yang meliputi dukungan keluarga khususnya suami. Dalam asuhan pasca persalinan dukungan keluarga sangat diperlukan. Seperti diketahui bahwa di Indonesia keputusan suami dan arahan dari ibu sangat berpengaruh dan menjadi pedoman penting bagi siibu dalam praktek asuhan bayinya sehari-hari. Bila suami dan keluarga tidak mendukung ibu pasca melahiran biasanya merasa sedih dan kewalahan dalam mengauh bayinya dihari-hari pertama setelah melahirkan. Dukungan suami dapat melemahan dampak stres atau tekanan dan secara lansung memperkokoh kesehatan mental individu dan keluarga, maka dukungan suami sangat dibutuhkan perempuan setelah mengalami persalinan.

Post Partum Blues atau gangguan mental pasca persalinan sering kali ditangani dan baik. Banyak ibu yang berjuang sendiri dalam beberapa saat setelah melahirkan. Mereka merasakan ada suatu hal yang salah namun merea sendiri tidak benar-benar mengetahui apa yang sedang terjadi. Apabila mea pergi mengunjungi dokter atau sumber-sumber lainya untuk minta pertolongan, seringali hanya mendapatan saran untuk beristirah atau tidur lebih banyak, tidak gelisah, minum obat atau berhenti mengasihani diri sendiri dan mulai merasa gembira menyambut kedatangan bayi yang mereka cintai. 
e-ISSN: 2541-4542

\section{KESIMPULAN}

Berdasarkan hasil uji Chisquare diperoleh hasil bahwa $p$ value $(0,003)<\alpha(0,05)$ sehingga dapat disimpulkan bahwa ada hubungan dukungan suami dengan kejadian post partum blues di wilayah perkotaan.

\section{UCAPAN TERIMA KASIH}

Terima kasih kepada Tempat Meneliti (Puskesmas Massenga) untuk menigkatkan mutu pelayanan kesehatan khususnya pada ibu nifas(pasca persalinan) dan menigkatkan derajat kesehatan pada ibu nifas secara optimal dan dapat memperluas wawasan dengan cara memberikan penyuluhan kepada ibu nifas sehingga resiko post partum blues dapat dicegah secara maksimal.

\section{DAFTAR RUJUKAN}

[1] D. Astuti, Indanah, and E. D. Rahayu, "Hubungan Dukungan Sosial Dan Kondisi Bayi Dengan Kejadian Postpartum Blues Pada Ibu Nifas Di Rumah Sakit the Relation Social Support and Baby Conditions With Postpartum Blues Events on the Nifas Mother in Hospital Permat," pp. 143-154, 2019.

[2] M. Qiftiyah, "Gambaran Faktor-Faktor (Dukungan Keluarga, Pengetahuan, Status Kehamilan Dan Jenis Persalinan) Yang Melatarbelakangi Kejadian Post Partum Blues Pada Ibu Nifas Hari Ke-7 (Di Polindes Doa Ibu Gesikharjo dan Polindes Teratai Kradenan Palang)," J. Kebidanan, vol. 10, no. 2, p. 9, 2018.

[3] L. W. Susanti, "Faktor Terjadinya Baby Blues Syndrom pada Ibu Nifas di BPM Suhatmi Puji Lestari," Matern. J. Kebidanan dan Ilmu Kesehanatan, vol. 3, no. 2, 2016.

[4] A. Kebidanan, P. Husada, J. Gerbang, and K. Kutai, "Pengalaman menjadi orang jiwa sebelumnya serta gangguan Menurut penelitian anak dari ibu yang mengalami dapat depresi mengalami tua khususnya seorang ibu kadang kala tidak selalu menjadi hal yang menyenangkan bagi setiap wanita atau pasangan suami istri .," pp. 99-106, 2015.

[5] S. N. Lisna Anisa Fitriana, "Gambaran Kejadian Postpartum Blues Pada Ibu Postpartum Remaja,” J. Pendidik. Keperawatan Indones. Vol.2 No. 1 Juli 2016, vol. 2, no. 1, pp. 44-51, 2014.

[6] P. P. Blues and M. Kurniasari, "BAB I,” no. 2015, pp. 1-4, 2017.

[7] M. Fairus and S. Widiyanti, "Hubungan Dukungan Suami dengan Kejadian Depresi Postpartum pada Ibu Nifas," J. Kesehat. Metro Sai Wawai, vol. VII, no. 1, pp. 11$18,2014$.

[8] Dinarum and H. Rosyidah, "Literatur Review: Pengaruh Dukungan Suami 
Terhadap Kejadian Postpartum Blues,” no. 1, pp. 90-95, 2020.

[9] S. Fatimah, "POSTPARTUM BLUES PADA IBU PRIMIPARA SEMARANG Oleh SITI FATIMAH NIM G2B308040 PROGRAM STUDI ILMU KEPERAWATAN UNIVERSITAS DIPONEGORO,” E-Journal Undip, no. Postpartum, p. 10, 2009.

[10] A. K. Fitrah, S. Helina, and H. Hamidah, "Hubungan Dukungan Suami Teradap Kejadian Postpartum Blues Di Wilayah Kerja Puskesmas Payung Sekaki Kota Pekanbaru Tahun 2017," J. Prot. Kesehat., vol. 7, no. 1, pp. 45-52, 2019.

[11] D. Ernawati, W. O. Merlin, and I. Ismarwati, "Kejadian Postpartum Blues pada Ibu Postpartum di RS PKU Muhammadiyah Yogyakarta," J. Ners dan Kebidanan (Journal Ners Midwifery), vol. 7, no. 2, pp. 203-212, 2020.

[12] B. Susilawati, E. R. Dewayani, W. Oktaviani, and A. Rahadhian, "Faktor-Faktor Yang Mempengaruhi Kejadian Post Partum Blues Di RS Akademik Universitas Gadjah Mada Postpartum blues wanita pasca persalinan. Periode ketidak kedua pasca melahirkan, dicirikan oleh wawancara yang dilakukan di Rumah Sakit Akademik UGM didapatkan data Journal of Nursing Care \& Biomolecular - Vol 5 No 1 Tahun 2020 - 78," vol. 5, no. 1, pp. 77-86, 2019.

[13] U. S. Ratulangi, "Dukungan suami dengan kejadian depresi pasca melahirkan," vol. 7, 2019.

[14] "Hubungan Dukungan Suami Dengan Tingkat Depresi Ibu Postpartum di Puskesmas Trauma Center Samarinda," vol. 2, no. 2, pp. 771-777, 2021.

[15] I. S. Arimurti, R. D. Pratiwi, and A. R. Ramadhina, "STUDI LITERATUR FAKTOR-FAKTOR YANG MEMPENGARUHI,” vol. 4, no. 2, pp. 29-37, 2020.

[16] D. I. K. Sukoharjo, “DEPRESI POSTPARTUM PADA IBU NIFAS,” vol. III, no. 2, pp. 36-41, 2019.

[17] A. Fatmawati and N. Gartika, "Hubungan Kondisi Psikososial Dan Paritas Dengan Kejadian Depresi Postpartum Pada Ibu Remaja The Relationship of Psychosocial Condition and Parity with Postpartum Depression Incidence in Adolescent Mothers," vol. 8, no. 1, pp. 36-41, 2021.

[18] C. Dent, “Cakradonya Dent J; 12(2): 104-110,” vol. 12, no. 2, pp. 104-110.

[19] A. D. Ristanti and E. D. Masita, “THE INFLUENCE OF HUSBAND' S SUPPORT ON HEALTH-SEEKING BEHAVIOR IN MADURESE MOTHERS WITH POSTPARTUM BLUES The 7th International Conference on Public Health The 7th International Conference on Public Health Solo, Indonesia, November 18-19, 2020 | 64,” pp. 63-68, 2020.

[20] K. Kesehatan et al., "Faktor yang berhubungan dengan kejadian postpartum blues di wilayah puskesmas remaja tahun 2020,” 2020. 